\title{
Communication
}

\section{Total Synthesis of a Marine Alkaloid-Rigidin E}

\section{Banpeng Cao, Haixin Ding, Ruchun Yang, Xiaoji Wang * and Qiang Xiao *}

Jiangxi Key Laboratory of Organic Chemistry, Jiangxi Science and Technology Normal University, Nanchang 330013, China; E-Mails: caobanpeng@126.com (B.C.); dinghaixin@ yahoo.cn (H.D.); ouyangruchun@yahoo.cn (R.Y.)

* Authors to whom correspondence should be addressed; E-Mails: 13767101659@163.com (X.W.); xiaoqiang@tsinghua.org.cn (Q.X.); Tel.: +86-791-86422903; Fax: +86-791-86422903.

Received: 28 May 2012; in revised form: 7 June 2012 / Accepted: 8 June 2012 /

Published: 20 June 2012

\begin{abstract}
In the present paper, we report an efficient total synthesis of a marine alkaloid, rigidin E. The key tetrasubstituted 2-amino-3-carboxamidepyrrole intermediate was synthesized by cascade Michael addition/intramolecular cyclization between $\mathrm{N}$-(2-(4-(benzyloxy)phenyl)-2-oxoethyl)methanesulfonamide and 3-(4-(benzyloxy) phenyl)-2-cyano- $N$-methylacrylamide. Subsequent carbonylation with triphosgene catalyzed by $I_{2}$ and deprotection of benzyl groups afforded rigidin $\mathrm{E}$ in $21 \%$ overall yield. This strategy has the merits of metal-free reactions, low cost, mild reaction protocols, and easy access to diversity-oriented derivatives for potential structure-activity relationship investigation.
\end{abstract}

Keywords: pyrrolo[2,3-d]pyrimidine; alkaloids; total synthesis; domino reaction; marine natural products

\section{Introduction}

Rigidin A (1), a pyrrolo[2,3- $d$ ]pyrimidine alkaloid, was first isolated by Kobayashi et al. from Okinawa marine tunicate Eudisromu cf. rigida in 1990 [1]. Later on, a series of its analogues, Rigidin B-E (2-5) (Figure 1), which were consequently isolated from the same marine species [2], were found to have strong inhibitory activity against calmodulin brain phosphodiesterase [3]. The core structure of rigidin A-E is a tetrasubstituted pyrrole fused to a pyrimidine, which is an important structural subunit in a variety of biologically active compounds. In the past decades, much attention 
have been drawn on the pyrrolo[2,3- $d]$ pyrimidine analogues for biological and pharmaceutical applications [4-11].

Figure 1. Structures of marine alkaloids rigidin A-E.

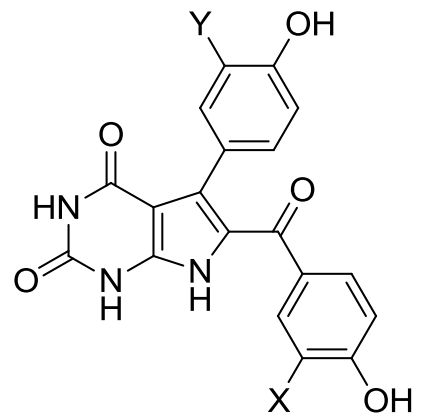

1, $\mathrm{X}=\mathrm{Y}=\mathrm{H}$, Rigidin A

2, $\mathrm{X}=\mathrm{OCH}_{3}, \mathrm{Y}=\mathrm{H}$, Rigidin $\mathrm{B}$

3, $\mathrm{X}=\mathrm{H}, \mathrm{Y}=\mathrm{OCH}_{3}$, Rigidin $\mathrm{C}$

4, $\mathrm{X}=\mathrm{Y}=\mathrm{OCH}_{3}$, Rigidin D

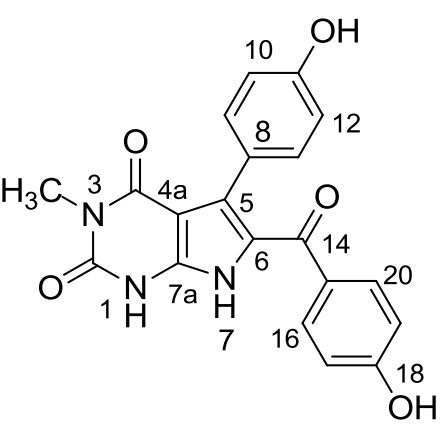

5, Rigidine E

Due to the fact that the content of rigidins in localized tunicate species is very low $(0.0015 \%$ wet weight), only very limited amount of rigidins could be isolated for biological study. Therefore, total synthesis of rigidin was employed to provide sufficient samples for their biological assays.

Currently, there are four published synthetic routes for the total synthesis of rigidins. In 1993, Edstrom et al. presented the first report of total synthesis of rigidin A (1) with 1,3-dibenzyl protected 6-chlorouracil in $26 \%$ overall yield [12]. After a $S_{N} 2$ substitution of the 6-chloro group with $N$-benzylglycine, the pyrrolo[2,3- $d$ ]pyrimidine skeleton was formed by reflux in acetic anhydride. The two substitutes at 5- and 6-position were then attached on Stille cross-coupling and Friedel-Crafts acylation respectively.

Soon after, Sakamoto and his co-workers reported the second strategy for total synthesis of rigidin A (1) in 1994 [13,14]. With a multi-substituted bromopyrimidine as starting material, the pyrrolo[2,3-d]pyrimidine core was built by Stille cross-coupling reaction with vinylstannane and subsequent acidic hydrolysis. The two substitutes were then introduced by similar reactions reported by Edstrom [12]. Rigidin A (1) was obtained in less than $10 \%$ overall yield.

In 2006, Gupton et al. reported the third total synthesis strategy for rigidin A (1) and rigidin E (5), which used a symmetrical vinamidinium salt to construct 2,4-disubstituted pyrrole [15]. After C-6 substitute was introduced by Friedel-Crafts acylation, the pyrimidine moiety was constructed to accomplish the total synthesis of rigidin A (1) and rigidin E (5).

The first and second synthetic routes employed substituted pyrimidine as the starting material and subsequently constructed the pyrrole moiety. In contrast, the third route constructed multi-substituted pyrrole moiety before pyrimidine formation. All three routes suffered from harsh reaction conditions, expensive Palladium-based catalyst, lengthy route and lack of variability for diversity-oriented derivatives.

In 2011, Magedov reported that tetra- and pentasubstituted 2-aminopyrroles can be prepared via multi-component reactions of structurally diverse aldehydes and $N$-(aryl-, heteroaryl-, alkylsulfonamido) acetophenones with cyanoacetic acid derivatives, such as malononitrile and cyanoacetate [16]. Furthermore, this methodology was used successfully in total synthesis of rigidins A-D in moderate 
overall yield, which is the fourth total synthetic route [16]. So far, this is the most efficient total synthetic strategy. However, this protocol's generality and reproducibility still needs to be proved. We describe herein an improved and practical synthetic route for the total synthesis of rigidin E.

\section{Results and Discussion}

Rigidin E contains many $H$-bond donor/acceptors, which may coordinate with heavy metal ions and form metal-rigidin complexes. The resulting metal contamination cannot usually be easily removed by a normal purification process. This promoted us to develop a metal-free strategy.

Our retrosynthetic analysis is showed in Figure 2. Principally, rigidin E may be synthesized from rigidin A through regioselective methylation at $\mathrm{N}-3$. This reaction is very difficult to realize due to the three $\mathrm{NH}$ groups in rigidin $\mathrm{E}$. Therefore, it is preferable to introduce the methyl group before constructing the tetrasubstituted 2-aminopyrrole.

Figure 2. Retrosynthetic analysis of rigidin E.

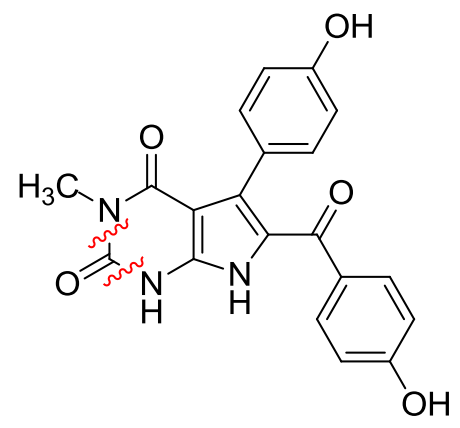

5, Rigidine E

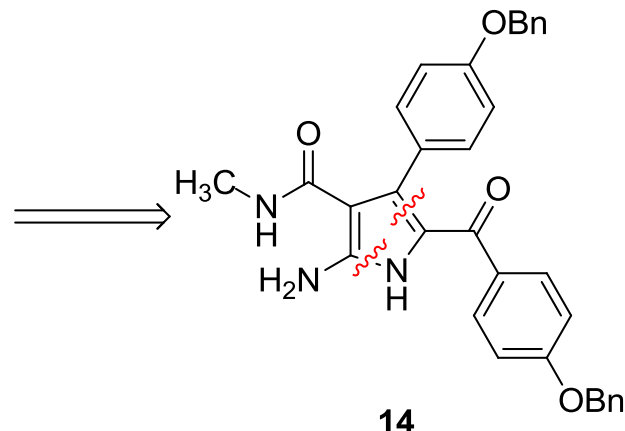

14

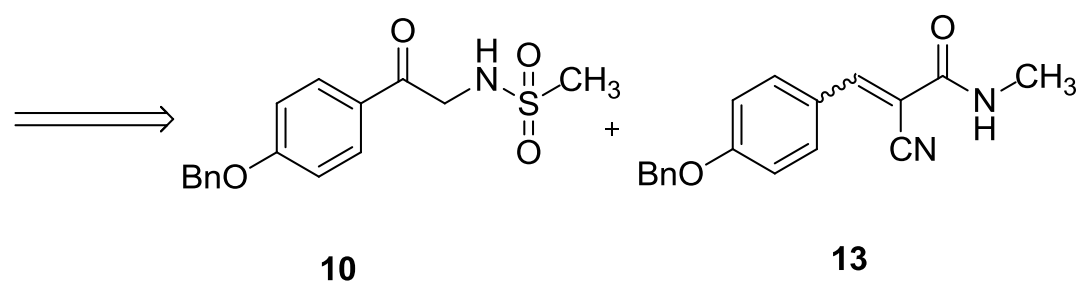

Regioselective bromination of acetophenone 7 with phenyltrimethylammonium tribromide in anhydrous THF afforded 2-bromoacetophenone $\mathbf{8}$ in $80 \%$ yield [17]. 2-Amino-acetophenone 9 was synthesized using hexamethylenetetramine as an $\mathrm{NH}_{2}$ source in anhydrous chlorobenzene. Subsequent reaction with methanesulfonyl chloride gave methanesulfonamide $\mathbf{1 0}$ in $60 \%$ yield over two steps (Scheme 1).

In order to introduce the methyl group to N-3, 2-cyano- $N$-methylacetamide 11 was synthesized from ethyl cyanoacetate and methylamine in $90 \%$ yield $[18,19]$. Attempts to synthesize key intermediate $\mathbf{1 4}$ using the reported three-components reaction of compound 10, 11, and $\mathbf{1 2}$ proceeded in very low yield and was complicated by undesired byproducts (Scheme 2). As reported by Magedov [16], Knoevenagel adduct $\mathbf{1 3}$ may be the intermediate in the three-component reaction. We speculated that the intermediate 13 could not form efficiently because of the higher $\mathrm{p} K_{\mathrm{a}}$ of the methylene of $N$-methylacetamide compare to $N$-unsubstituted acetamide. Therefore, it is possible to solve this problem through synthesis of the intermediate $\mathbf{1 3}$ independently. 
Scheme 1. Synthesis of methanesulfonamide 10. Reagents and conditions: (a) $\mathrm{K}_{2} \mathrm{CO}_{3}$, acetone, $\mathrm{BnBr}, 0{ }^{\circ} \mathrm{C}$, 98\%; (b) phenyltriethylammonium tribromide, THF, 80\%; (c) hexamethylenetetramine, chlorobenzene, then conc. $\mathrm{HCl}$; (d) $\mathrm{MsCl}, \mathrm{Et}_{3} \mathrm{~N}$, acetone/ $\mathrm{H}_{2} \mathrm{O}$ 2:1, $60 \%$ over two steps.<smiles>O=CC(=O)c1ccc(O)cc1</smiles>

6
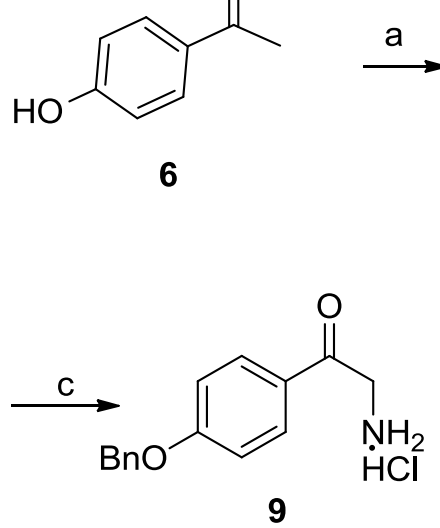<smiles>CC(=O)c1ccc(OCc2ccccc2)cc1</smiles>

7<smiles>O=C(CBr)c1ccc(OC(=O)c2ccccc2)cc1</smiles>

8<smiles>CC(C)Oc1ccc(C(=O)CNS(C)(=O)=O)cc1</smiles>

10

Scheme 2. Three-components reaction for synthesis the key intermediate $\mathbf{1 4}$ failed. Reagents and conditions: (a) $\mathrm{K}_{2} \mathrm{CO}_{3}$, EtOH, reflux.<smiles>O=Cc1ccc(OCc2ccccc2)cc1</smiles>

12<smiles>CNC(=O)CC#N</smiles>

11<smiles>CC(C)(C)Oc1ccc(C(=O)CNS(C)(=O)=O)cc1</smiles>

10<smiles>CNC(=O)c1c(N)[nH]c(C(=O)c2ccc(OCc3ccccc3)cc2)c1-c1ccc(CC(C)C)cc1</smiles>

14

After Knoevenagel condensation of 2-cyano- $N$-methylacetamide 11 and 4-(benzyloxy)benzaldehyde 12 using piperidine as a catalyst, 3-(4-(benzyloxy)phenyl)-2-cyano- $N$-methylacrylamide 13 was obtained in $80 \%$ yield as a mixture of $E / Z$ in about 1:1 ratio (Scheme 3) [20]. Then, a variation of the reported three-components reaction was conducted to synthesize the precursor 14.

Scheme 3. Synthesis of $N$-methylacrylamide 13. Reagents and conditions: (a) methylamine, $\mathrm{H}_{2} \mathrm{O}, 90 \%$; (b) $\mathrm{K}_{2} \mathrm{CO}_{3}$, acetone, $\mathrm{BnBr}, 0{ }^{\circ} \mathrm{C}, 95 \%$; (c) 11, piperidine, toluene, $80 \%$.<smiles>CNC(=O)CC#N</smiles><smiles>CNC(=O)/C(=C/c1ccc(OC(C)C)cc1)CN</smiles> 
After a careful screening of reaction conditions, the key intermediate $\mathbf{1 4}$ was successfully prepared by a cascade Michael addition/intermolecular cyclization between $N$-methylacrylamide $\mathbf{1 3}$ and methanesulfonamide $\mathbf{1 0}$ in one pot, with $\mathrm{K}_{2} \mathrm{CO}_{3}$ as base and ethanol as solvent under refluxing conditions. The present result proves that phenyl-2-cyanoacrylamide like Knoevenagel adduct was the intermediate for cyclization in the reported three-component reaction [21].

Carbonylation with oxalyl chloride in diglyme failed to give pyrimidinedione $\mathbf{1 5}$ [16]. Various reagents and conditions were tested, and triphosgene was found ideal to promote the $\mathrm{I}_{2}$-catalyzed cyclization in anhydrous THF to give pyrimidinedione $\mathbf{1 5}$ in $60 \%$ yield [22,23]. The final deprotection of benzyl groups using catalytic hydrogenation resulted in a complicated mixture. The reason might be the accompanied reduction of carbonyl at C-14. Finally, the protective groups were successfully removed by TMSI in situ prepared by TMSCl and $\mathrm{NaI}$ to afford rigidin E (5) in $88 \%$ yield (Scheme 4). All spectral data are consistent with those of the reported natural product [3].

Scheme 4. Total synthesis of rigidin E. Reagents and conditions: (a) $\mathrm{K}_{2} \mathrm{CO}_{3}$, EtOH, reflux, $50 \%$; (b) triphosgene, $\mathrm{I}_{2}$, THF, 60\%; (c) TMSCl, NaI, $\mathrm{CH}_{3} \mathrm{CN}, 88 \%$.<smiles>CNC(=O)/C(C#N)=C(\C#N)C(=O)NS(C)(=O)=O</smiles><smiles>CNC(=O)c1c(N)[nH]c(C(=O)c2ccc(OCc3ccccc3)cc2)c1-c1ccc(OCc2ccc(OCc3ccc(OCc4ccccc4)cc3)cc2)cc1</smiles>

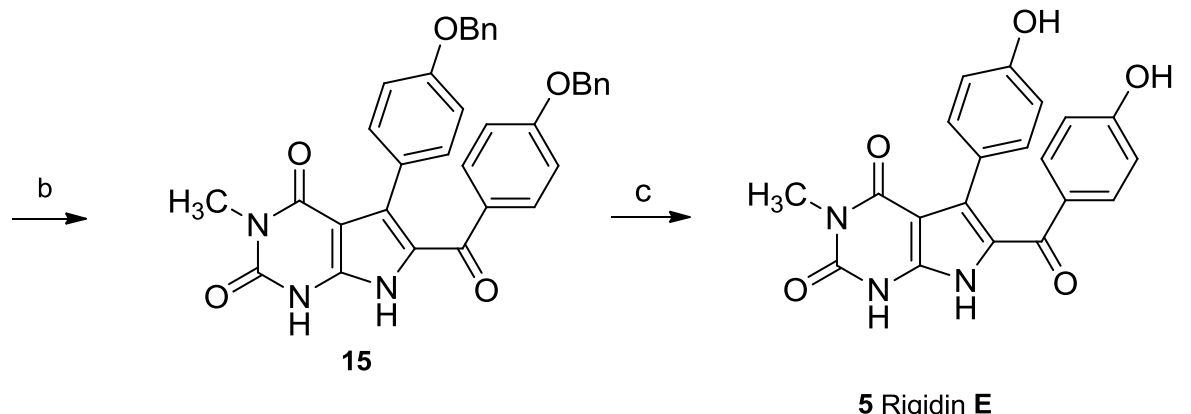




\section{Experimental Section}

\subsection{General}

All reagents and catalysts were purchased from commercial sources (Acros or Sigma Aldrich) and used without purification. MeCN, chlorobenzene and DCM were dried with $\mathrm{CaH}_{2}$ and distilled prior to use. THF was dried with $\mathrm{LiAlH}_{4}$ and distilled prior to use. Thin layer chromatography was performed using silica gel GF-254 plates (Qing-Dao Chemical Company, China) with detection by UV (254 nm) or charting with $10 \%$ sulfuric acid in ethanol. Column chromatography was performed on silica gel (200-300 mesh, Qing-Dao Chemical Company, China). NMR spectra were recorded on a Bruker AV400 spectrometer, and chemical shifts $(\delta)$ are reported in $\mathrm{ppm} .{ }^{1} \mathrm{H}$ NMR and ${ }^{13} \mathrm{C}$ NMR spectra were calibrated with TMS as internal standard, and coupling constants $(J)$ are reported in Hz. The ESI-HRMS were obtained on a Bruker Dalton microTOFQ II spectrometer in positive ion mode. Melting points were measured on an electrothermal apparatus uncorrected.

\subsection{1-(4-(Benzyloxy)phenyl)-2-bromoethanone $\mathbf{8}$}

To a solution of 1-(4-(benzyloxy)phenyl)ethanone $7(2.26 \mathrm{~g}, 10 \mathrm{mmol})$ in anhydrous THF $(20 \mathrm{~mL})$ was added phenyltrimethylammonium tribromide $(3.76 \mathrm{~g}, 10 \mathrm{mmol})$. The resulting solution was stirred at room temperature. A white precipitate was formed and the solution became yellowish over several minutes. After $30 \mathrm{~min}$, the mixture was poured into ice water $(50 \mathrm{~mL})$ and extracted with ethyl acetate $(20 \mathrm{~mL} \times 3)$. The combined organic layer was dried over anhydrous $\mathrm{Na}_{2} \mathrm{SO}_{4}$, filtered, and concentrated. The crude product was recrystallized from ethanol $(15 \mathrm{~mL})$ to afford the title product 8 (2.43 g, 80\% yield).

MP: $67-69{ }^{\circ} \mathrm{C} ; R_{f}=0.30(\mathrm{PE}-\mathrm{EtOAc}, 50: 1) .{ }^{1} \mathrm{H} \mathrm{NMR}\left(400 \mathrm{MHz}, \mathrm{CDCl}_{3}\right): \delta=4.40\left(\mathrm{~s}, 2 \mathrm{H}, \mathrm{CH}_{2} \mathrm{Br}\right)$, $5.14\left(\mathrm{~s}, 2 \mathrm{H}, \mathrm{C}_{6} \mathrm{H}_{5} \mathrm{CH}_{2}\right), 7.03$ (d, $\left.J=8.8 \mathrm{~Hz}, 2 \mathrm{H}, \mathrm{C}_{6} \mathrm{H}_{4}, \mathrm{H}-3,5\right), 7.35-7.44\left(\mathrm{~m}, 5 \mathrm{H}, \mathrm{C}_{6} \mathrm{H}_{5}\right), 7.96$ (d, $\left.J=8.8 \mathrm{~Hz}, 2 \mathrm{H}, \mathrm{C}_{6} \mathrm{H}_{4}, \mathrm{H}-2,4\right) .{ }^{13} \mathrm{C} \mathrm{NMR}\left(100 \mathrm{MHz}, \mathrm{CDCl}_{3}\right): \delta=30.7,70.2,114.9,127.5,128.3,128.7$, 130.6, 131.4, 135.9, 163.3, 190.0. MS (ESI): $m / z=304.8[\mathrm{M}+\mathrm{H}]^{+}$.

\subsection{N-(2-(4-(Benzyloxy)phenyl)-2-oxoethyl)methanesulfonamide $\mathbf{1 0}$}

1-(4-(Benzyloxy)phenyl)-2-bromoethanone 8 (3.04 g, $10 \mathrm{mmol})$ was dissolved in anhydrous chlorobenzene $(8.5 \mathrm{~mL})$. The solution was added dropwise to a solution of hexamethylenetetramine $(1.15 \mathrm{~g}, 11 \mathrm{mmol})$ in anhydrous chlorobenzene $(10 \mathrm{~mL})$ at $30^{\circ} \mathrm{C}$. The reaction mixture was stirred at $30{ }^{\circ} \mathrm{C}$ for $4 \mathrm{~h}$ and filtered. The filter cake was washed with ethanol $(10 \mathrm{~mL})$ and dried in vacuo. The filter cake was redissolved in a mixture of concentrated hydrochloric acid $(10 \mathrm{~mL})$ and ethanol $(20 \mathrm{~mL})$ with vigorous stirring. The resulting reaction mixture was stirred occasionally under $\mathrm{N}_{2}$ atmosphere for $48 \mathrm{~h}$. The reaction mixture was cooled to $0{ }^{\circ} \mathrm{C}$ and filtered to give compound 9 . It was redissolved in $\mathrm{H}_{2} \mathrm{O}$ /acetone $(1: 2,600 \mathrm{~mL})$. Then methanesulfonyl chloride $(1.71 \mathrm{~g}, 15 \mathrm{mmol})$ was added to the mixture. The mixture was placed in an ice bath and triethylamine $(2.53 \mathrm{~g}, 25 \mathrm{mmol})$ was added dropwise over $30 \mathrm{~min}$. Then acetone $(14 \mathrm{~mL})$ was added to the above mixture. The reaction mixture was stirred at room temperature for $10 \mathrm{~h}$, and then the volatiles were evaporated under reduced pressure. The solid started to precipitate. To the obtained slurry were added ethyl acetate $(20 \mathrm{~mL})$ and 
saturated $\mathrm{NH}_{4} \mathrm{Cl}(20 \mathrm{~mL})$ aqueous solution. The organic layer was separated and washed with saturated $\mathrm{NaHCO}_{3}(20 \mathrm{~mL})$ aqueous solution and brine $(20 \mathrm{~mL})$, dried with anhydrous $\mathrm{MgSO}_{4}$, and concentrated to afford the title product $\mathbf{1 0}(1.91 \mathrm{~g}, 60 \%$ yield $)$.

$\mathrm{Mp}: 138-140{ }^{\circ} \mathrm{C} ; R_{f}=0.43\left(\mathrm{CH}_{3} \mathrm{OH}-\mathrm{CH}_{2} \mathrm{Cl}_{2}, 1: 50\right) .{ }^{1} \mathrm{H}$ NMR $\left(400 \mathrm{MHz}, \mathrm{CDCl}_{3}\right): \delta=2.99(\mathrm{~s}, 3 \mathrm{H}$, $\left.\mathrm{CH}_{3}\right), 4.61\left(\mathrm{~s}, 2 \mathrm{H}, \mathrm{CH}_{2} \mathrm{NH}\right), 5.15\left(\mathrm{~s}, 2 \mathrm{H}, \mathrm{C}_{6} \mathrm{H}_{5} \mathrm{CH}_{2}\right), 5.32-5.49(\mathrm{~b}, 1 \mathrm{H}, \mathrm{NH}), 7.04$ (d, J=8.8 Hz, 2H, $\left.\mathrm{C}_{6} \mathrm{H}_{4}, \mathrm{H}-3,5\right), 7.25-7.42\left(\mathrm{~m}, 5 \mathrm{H}, \mathrm{C}_{6} \mathrm{H}_{5}\right), 7.91\left(\mathrm{~d}, J=8.8 \mathrm{~Hz}, 2 \mathrm{H}, \mathrm{C}_{6} \mathrm{H}_{4}, \mathrm{H}-2,4\right) .{ }^{13} \mathrm{C}$ NMR $(100 \mathrm{MHz}$, $\left.\mathrm{CDCl}_{3}\right): \delta=40.7,48.8,70.3,115.1,126.9,127.5,128.4,128.7,130.3,135.8,163.7,191.6 . \mathrm{MS}$ (ESI): $\mathrm{m} / \mathrm{z}=342.5[\mathrm{M}+\mathrm{Na}]^{+}$.

\subsection{4-(Benzyloxy)benzaldehyde $\mathbf{1 2}$}

To a mixture of 4-hydroxybenzaldehyde $(1.22 \mathrm{~g}, 10 \mathrm{mmol})$ and $\mathrm{K}_{2} \mathrm{CO}_{3}(1.45 \mathrm{~g}, 10.5 \mathrm{mmol})$ in acetone $(10 \mathrm{~mL})$ was added benzyl bromide $(1.80 \mathrm{~g}, 10.5 \mathrm{mmol})$. The resulting mixture was heated to reflux for $3 \mathrm{~h}$. After cooling, the reaction mixture was poured into water $(5 \mathrm{~mL})$ and extracted with $\mathrm{Et}_{2} \mathrm{O}(5 \mathrm{~mL} \times 3)$. The combined organic layers were washed with brine $(20 \mathrm{~mL})$, dried over anhydrous $\mathrm{MgSO}_{4}$, filtered, and concentrated under reduced pressure to give a white solid. The solid was washed with $95 \%$ ethanol $(2 \mathrm{~mL})$ to afford pure product $12(2.01 \mathrm{~g}, 95 \%$ yield $)$.

MP: $69-71{ }^{\circ} \mathrm{C} ; R_{f}=0.49$ (PE-EtOAc, 4:1). ${ }^{1} \mathrm{H}$ NMR $\left(400 \mathrm{MHz}, \mathrm{CDCl}_{3}\right): \delta=5.15(\mathrm{~s}, 2 \mathrm{H}$, $\left.\mathrm{C}_{6} \mathrm{H}_{5} \mathrm{CH}_{2}\right), 7.08\left(\mathrm{~d}, J=8.4 \mathrm{~Hz}, 2 \mathrm{H}, \mathrm{C}_{6} \mathrm{H}_{4}, \mathrm{H}-3,5\right), 7.35-7.45\left(\mathrm{~m}, 5 \mathrm{H}, \mathrm{C}_{6} \mathrm{H}_{5} \mathrm{CH}_{2}\right), 7.84(\mathrm{~d}, J=8.4 \mathrm{~Hz}$, $\left.2 \mathrm{H}, \mathrm{C}_{6} \mathrm{H}_{4}, \mathrm{H}-2,4\right), 9.89$ (s, 1H, CHO). ${ }^{13} \mathrm{C} \mathrm{NMR}\left(100 \mathrm{MHz}, \mathrm{CDCl}_{3}\right): \delta=70.6,115.5,127.8,128.6$, 129.1, 130.5, 132.3, 136.3, 164.1, 191.1. MS (ESI): $m / z=213.2[\mathrm{M}+\mathrm{Na}]^{+}$.

\subsection{2-Cyano-N-methylacetamide}

To an ice cooled solution of methylamine $(2.17 \mathrm{~g}, 75 \mathrm{mmol})$ in water, ethyl cyanoacetate $(5.65 \mathrm{~g}$, $50 \mathrm{mmol}$ ) was added dropwise. The solution was stirred at room temperature for $3 \mathrm{~h}$. Most of the solvent were evaporated under reduced pressure. The obtained solid was filtered and redissolved in ethyl acetate $(200 \mathrm{~mL})$. The solution was dried over anhydrous $\mathrm{Na}_{2} \mathrm{SO}_{4}$. The solvent was evaporated to give the title product $(4.14 \mathrm{~g}, 90 \%$ yield $)$.

MP: $81-83{ }^{\circ} \mathrm{C} .{ }^{1} \mathrm{H}$ NMR (400 MHz, DMSO): $\delta=2.58\left(\mathrm{~d}, J=4.4 \mathrm{~Hz}, 3 \mathrm{H}, \mathrm{CH}_{3}\right), 3.57\left(\mathrm{~s}, 2 \mathrm{H}, \mathrm{CH}_{2}\right)$, $8.14(\mathrm{~s}, 1 \mathrm{H}, \mathrm{NH}) .{ }^{13} \mathrm{C}$ NMR $\left(100 \mathrm{MHz}, \mathrm{DMSO}-d_{6}\right): \delta=24.6,25.4,115.6,161.9 . \mathrm{MS}(\mathrm{ESI}): \mathrm{m} / z=99.4$ $[\mathrm{M}+\mathrm{H}]^{+}$.

\subsection{3-(4-(Benzyloxy)phenyl)-2-cyano-N-methylacrylamide $\mathbf{1 3}$}

To a mixture of 4-(benzyloxy)benzaldehyde $12(2.12 \mathrm{~g}, 10 \mathrm{mmol})$ and piperidine $(34 \mathrm{mg}, 0.4 \mathrm{mmol})$ in toluene $(10 \mathrm{~mL})$ was added 2-cyano- $N$-methylacetamide $(1.08 \mathrm{~g}, 11 \mathrm{mmol})$. The resulting mixture was heated to reflux for $15 \mathrm{~h}$. After cooling, the reaction mixture was filtered. The filter cake was washed with $95 \%$ ethanol $(20 \mathrm{~mL})$, and then dried in vacuo to afford the title product $\mathbf{1 3}$ (2.34 g, 80\% yield).

MP: $170-172{ }^{\circ} \mathrm{C} ; R_{f}=0.37$ (PE-EtOAc, 2:1). ${ }^{1} \mathrm{H}$ NMR (400 MHz, DMSO-d $)$ ): $\delta=2.72$ (d, $\left.J=4.4 \mathrm{~Hz}, 3 \mathrm{H}, \mathrm{CH}_{3}\right), 5.19\left(\mathrm{~s}, 2 \mathrm{H}, \mathrm{CH}_{2}\right), 7.18\left(\mathrm{~d}, J=8.8 \mathrm{~Hz}, 2 \mathrm{H}, \mathrm{C}_{6} \mathrm{H}_{4}, \mathrm{H}-3,5\right), 7.31-7.46(\mathrm{~m}, 5 \mathrm{H}$, $\left.\mathrm{C}_{6} \mathrm{H}_{5}\right), 7.95$ (d, $\left.J=8.8 \mathrm{~Hz}, 2 \mathrm{H}, \mathrm{C}_{6} \mathrm{H}_{4}, \mathrm{H}-2,4\right), 8.08(\mathrm{~s}, 1 \mathrm{H}, \mathrm{NH}), 8.27\left(\mathrm{~d}, J=4.4 \mathrm{~Hz}, 1 \mathrm{H}, \mathrm{CH}_{2}\right)$. 
${ }^{13} \mathrm{C}$ NMR $\left(100 \mathrm{MHz}, \mathrm{DMSO}-d_{6}\right): \delta=27.2,70.0,103.0,116.0,117.4,125.1,128.4,128.5,129.0$, 132.9, 136.8, 150.4, 162.0. MS (ESI): $m / z=315.1[\mathrm{M}+\mathrm{H}]^{+}$.

\subsection{2-Amino-5-(4-(benzyloxy)benzoyl)-4-(4-(benzyloxy)phenyl)-N-methyl-1h-pyrrole-3-carboxamide 14}

To a mixture of 3-(4-(benzyloxy)phenyl)-2-cyano- $N$-methylarcylamide $\mathbf{1 3}$ (3.21 g, $11 \mathrm{mmol})$ and $\mathrm{K}_{2} \mathrm{CO}_{3}(0.69 \mathrm{~g}, 5 \mathrm{mmol})$ in ethanol $(10 \mathrm{~mL})$ was added $N$-(2-(4-(benzyloxy)phenyl)-2-oxoethyl) methanesulfonamide 10 (3.19 g, $10 \mathrm{mmol})$. The resulting mixture was refluxed for $12 \mathrm{~h}$ under $\mathrm{N}_{2}$ atmosphere. After the solvent was evaporated, the residue was purified by column chromatography with $\mathrm{CH}_{3} \mathrm{OH} / \mathrm{CH}_{2} \mathrm{Cl}_{2}=1: 60$ to afford the title product 14 (2.66 g, 50\% yield).

MP 247-249 ${ }^{\circ} \mathrm{C} ; R_{f}=0.40\left(\mathrm{CH}_{3} \mathrm{OH}-\mathrm{CH}_{2} \mathrm{Cl}_{2}, 1: 60\right) .{ }^{1} \mathrm{H}$ NMR $\left(400 \mathrm{MHz}, \mathrm{DMSO}-d_{6}\right): \delta=2.46(\mathrm{~d}$, $\left.J=4.8 \mathrm{~Hz}, 3 \mathrm{H}, \mathrm{CONHCH}_{3}\right), 5.01\left(\mathrm{~s}, 2 \mathrm{H}, \mathrm{C}_{6} \mathrm{H}_{4} \mathrm{OCH}_{2} \mathrm{C}_{6} \mathrm{H}_{5}\right), 5.03\left(\mathrm{~s}, 2 \mathrm{H}, \mathrm{CH}_{2}\right), 5.24(\mathrm{~b}, 1 \mathrm{H}), 6.25$ (s, $\left.2 \mathrm{H}, \mathrm{NH}_{2}\right), 6.62(\mathrm{~d}, J=8.8 \mathrm{~Hz}, 2 \mathrm{H}), 6.77(\mathrm{~d}, J=8.4 \mathrm{~Hz}, 2 \mathrm{H}), 6.94(\mathrm{~d}, J=8.4 \mathrm{~Hz}, 2 \mathrm{H}), 7.09(\mathrm{~d}, 2 \mathrm{H}$, $J=8.8 \mathrm{~Hz}), 7.33-7.36(\mathrm{~b}, 10 \mathrm{H}), 10.80(\mathrm{~s}, 1 \mathrm{H}) .{ }^{13} \mathrm{C}$ NMR $\left(100 \mathrm{MHz}, \mathrm{DMSO}-d_{6}\right): \delta=25.7,69.8,99.2$, 113.6, 114.7,121.5, 126.5, 127.8, 128.2, 128.7, 130.2, 131.0, 132.1, 132.2, 137.0, 137.2, 148.8, 158.2, 159.8, 166.3, 183.3. MS (ESI): $\mathrm{m} / z=570.2[\mathrm{M}+\mathrm{K}]^{+}$.

3.8. 6-(4-(Benzyloxy)benzoyl)-5-(4-(benzyloxy)phenyl)-3-methyl-1H-pyrrolo[2,3-d]pyrimidine-2,4 (3H,7H)-dione 15

A mixture of pyrrolocarboxamide $14(5.31 \mathrm{~g}, 10.0 \mathrm{mmol})$, triphosgene $(1.48 \mathrm{~g}, 5.0 \mathrm{mmol})$ and iodine $(0.127 \mathrm{~g}, 0.5 \mathrm{mmol})$ in anhydrous THF $(10 \mathrm{~mL})$ was heated to reflux for $20 \mathrm{~h}$ before the volatiles were removed in vacuo. The residue was dissolved in ethyl acetate $(10 \mathrm{~mL})$ and washed with brine $(10 \mathrm{~mL})$, dried over anhydrous $\mathrm{MgSO}_{4}$, and purified by column chromatography $\left(\mathrm{MeOH} / \mathrm{CH}_{2} \mathrm{Cl}_{2}=1: 10\right)$ to afford the title product 15 (3.34 g, 60\% yield).

MP: $226-228{ }^{\circ} \mathrm{C} ; R_{f}=0.35\left(\mathrm{MeOH}-\mathrm{CH}_{2} \mathrm{Cl}_{2}, 1: 10\right) .{ }^{1} \mathrm{H}$ NMR $\left(400 \mathrm{MHz}, \mathrm{DMSO}-d_{6}\right): \delta=3.14(\mathrm{~s}, 3 \mathrm{H}$, $\left.\mathrm{CH}_{3}\right), 5.00\left(\mathrm{~s}, 2 \mathrm{H}, \mathrm{CH}_{2}\right), 5.03(\mathrm{~s}, 2 \mathrm{H}), 6.67-6.73(\mathrm{~m}, 4 \mathrm{H}), 7.03-7.05(\mathrm{~m}, 2 \mathrm{H}), 7.28-7.35(\mathrm{~m}, 12 \mathrm{H}), 11.65$ $(\mathrm{s}, 1 \mathrm{H}), 11.96(\mathrm{~s}, 1 \mathrm{H}) .{ }^{13} \mathrm{C}$ NMR $\left(100 \mathrm{MHz}, \mathrm{DMSO}-d_{6}\right): \delta=27.2,69.7,69.9,98.4,113.7,114.2,125.1$, 125.7, 127.9, 128.0, 128.2, 128.4, 128.9, 130.9, 131.7, 132.7, 136.9, 137.5, 140.1, 151.2, 158.0, 159.5, 161.4, 185.7. MS (ESI): $m / z=596.2[\mathrm{M}+\mathrm{Na}]^{+}$.

\subsection{Rigidin E 5}

A mixture of 6-(4-(benzyloxy)benzoyl)-5-(4-(benzyloxy)phenyl)-3-methyl-1H-pyrrolo[2,3- $d$ ] pyrimidine-2,4(3H,7H)-dione $15(1.114 \mathrm{~g}, 2 \mathrm{mmol})$ and $\mathrm{NaI}(9.0 \mathrm{~g}, 60 \mathrm{mmol})$ in $\mathrm{CH}_{3} \mathrm{CN}(20 \mathrm{~mL})$ under $\mathrm{N}_{2}$ was stirred at room temperature for $20 \mathrm{~min}$. Chlorotrimethylsilane $(17.8 \mathrm{~g}, 60 \mathrm{mmol})$ was then added. The mixture was stirred at $60{ }^{\circ} \mathrm{C}$ for $18 \mathrm{~h}$ before the volatiles were removed in vacuo. The residue was extracted with petroleum ether $(10 \mathrm{~mL} \times 3)$ in order to remove benzyl iodide, and then treated with water $(5 \mathrm{~mL})$ and ethyl acetate $(10 \mathrm{~mL})$. The mixture was stirred vigorously at room temperature for $2 \mathrm{~h}$ and extracted with more ethyl acetate $(40 \mathrm{~mL} \times 2)$. The combined organic layers were washed with brine $(5 \mathrm{~mL})$ containing a small amount of sodium thiosulfate, dried over anhydrous $\mathrm{MgSO}_{4}$, and purified by column chromatography (PE/Ethyl Acetate/MeOH/AcOH = 9:18:1:1) to afford the title product rigidin $\mathrm{E}$ (5) (664 mg, 88\% yield). 
$\mathrm{MP}>300{ }^{\circ} \mathrm{C} ; R_{f}=0.31$ (PE-Ethyl Acetate-MeOH-AcOH = 9:18:1:1). ${ }^{1} \mathrm{H}$ NMR $(400 \mathrm{MHz}$, DMSO- $\left.d_{6}\right): \delta=3.14\left(\mathrm{~s}, 3 \mathrm{H}, \mathrm{CH}_{3}\right), 6.44(\mathrm{t}, J=8.0 \mathrm{~Hz}, 4 \mathrm{H}), 6.93(\mathrm{~d}, J=7.6 \mathrm{~Hz}, 2 \mathrm{H}), 7.27(\mathrm{~d}, J=8.0 \mathrm{~Hz}$, $2 \mathrm{H}) .{ }^{13} \mathrm{C}$ NMR $\left(100 \mathrm{MHz}, \mathrm{DMSO}-d_{6}\right): \delta=27.2,98.2,114.2,114.7,123.4,125.3,128.7,129.2,132.0$, 132.8, 152.4, 156.8, 159.9, 161.0, 185.7. HRMS-ESI: $m / z$. $[\mathrm{M}+\mathrm{H}]^{+}$calcd for $\mathrm{C}_{20} \mathrm{H}_{15} \mathrm{~N}_{3} \mathrm{O}_{5}$ : 378.1012; found: 378.1098 .

\section{Conclusions}

In conclusion, we have developed an efficient approach for the total synthesis of rigidin E using readily available starting materials and routine chemical transformations. This strategy is especially useful to access different N-3 substituted rigidin derivatives.

\section{Acknowledgments}

We thank NSFC (No. 20962009, 21062006), NCET (11-1000), Education Department of Jiangxi Province (GJJ 11223) and Bureau of Science \& Technology of Nanchang City for financial support.

\section{References}

1. Kobayashi, J.; Cheng, J.; Kikuchi, Y.; Ishibashi, M.; Yamamura, S.; Ohizumi, Y.; Ohtac, T.; Nozoec, S. Rigidin, a novel alkaloid with calmodulin antagonistic activity from the okinawan marine tunicate Eudistoma cf. rigida. Tetrahedron Lett. 1990, 31, 4617-4620.

2. Tsuda, M.; Nozawa, K.; Shimbo, K.; Kobayashi, J. Rigidins B-D, new pyrrolopyrimidine alkaloids from a tunicate Cystodytes species. J. Nat. Prod. 2003, 66, 292-294.

3. Davis, R.A.; Christensen, L.V.; Richardson, A.D.; Da Rocha, R.M.; Ireland, C.M. Rigidin E, a new pyrrolopyrimidine alkaloid from a Papua New Guinea tunicate Eudistoma species. Mar. Drugs 2003, 1, 27-33.

4. Ölgen, S.; Isgör, Y.G.; Coban, T. Synthesis and Activity of Novel 5-Substituted Pyrrolo[2,3- $d]$ pyrimidine Analogues as pp60c-Src Tyrosine Kinase Inhibitors. Arch. Pharm. 2008, 341, 113-120.

5. Bhat, U.G.; Gartel, A.L. Differential sensitivity of human colon cancer cell lines to the nucleoside analogs ARC and DRB. Int. J. Cancer 2008, 122, 1426-1429.

6. Seela, F.; Peng, X.; Budow, S. Advances in the Synthesis of 7-Deazapurine-pyrrolo[2,3- $d$ ] pyrimidine 2'-Deoxyribonucleosides Including D- and L-Enantiomers, Fluoro Derivatives and 2',3'-Dideoxyribonucleosides. Curr. Org. Chem. 2007, 11, 427-462.

7. Matthew, M.; Xu, F.; Waters, M.; Williams, J.M.; Savary, K.A.; Cameron, J.; Yang, C.; Buck, E.; Song, Z.J.; Tschaen, D.M. Practical synthesis of a potent hepatitis C virus RNA replication inhibitor. J. Org. Chem. 2004, 69, 6257-6266.

8. Gangjee, A.; Vidwans, A.; Elzein, E.; McGuire, J.J.; Queener, S.F.; Kisliuk, R.L. Synthesis, antifolate, and antitumor activities of classical and nonclassical 2-amino-4-oxo-5-substituted-pyrrolo [2,3-d] pyrimidines. J. Med. Chem. 2001, 44, 1993-2003.

9. Renau, T.E.; Kennedy, C.; Ptak, R.G.; Breitenbach, J.M.; Drach, J.C.; Townsend, L.B. Synthesis of non-nucleoside analogs of toyocamycin, sangivamycin, and thiosangivamycin: The effect of certain 4- and 4,6-substituents on the antiviral activity of pyrrolo[2,3-d] pyrimidines. $J$. Med. Chem. 1996, 39, 3470-3476. 
10. Sun, J.; Dou, Y.; Ding, H.; Yang, R.; Sun, Q.; Xiao, Q. First Total Synthesis of a Naturally Occurring Iodinated 5'-Deoxyxylofuranosyl Marine Nucleoside. Mar. Drugs 2012, 10, 881-889.

11. Song, Y.; Ding, H.; Dou, Y.; Yang, R.; Sun, Q.; Xiao, Q.; Ju, Y. Efficient and practical synthesis of 5'-deoxytubercidin and its analogues via Vorbruggen glycosylation. Synthesis 2011, 2011, 1442-1446.

12. Edstrom, E.D.; Wei, Y. Synthesis of a novel pyrrolo[2,3-d] pyrimidine alkaloid, rigidin. J. Org. Chem. 1993, 58, 403-407.

13. Sakamoto, T.; Kondo, Y.; Sato, S.; Yamanaka, H. Condensed heteroaromatic ring systems. Part 24. Synthesis of rigidin, a pyrrolo[2,3-d] pyrimidine marine alkaloid. J. Chem. Soc. Perkin Trans. 1 1996, 459-464.

14. Sakamoto, T.; Kondo, Y.; Sato, S.; Yamanaka, H. Total synthesis of a marine alkaloid, rigidin. Tetrahedron Lett. 1994, 35, 2919-2920.

15. Gupton, J.T.; Banner, E.J.; Scharf, A.B.; Norwood, B.K.; Kanters, R.P.F.; Dominey, R.N.; Hempel, J.E.; Kharlamova, A.; Bluhn-Chertudi, I.; Hickenboth, C.R. The application of vinylogous iminium salt derivatives to an efficient synthesis of the pyrrole containing alkaloids Rigidin and Rigidin E. Tetrahedron 2006, 62, 8243-8255.

16. Frolova, L.V.; Evdokimov, N.M.; Hayden, K.; Malik, I.; Rogelj, S.; Kornienko, A.; Magedov, I.V. One-Pot Multicomponent Synthesis of Diversely Substituted 2-Aminopyrroles. A Short General Synthesis of Rigidins A, B, C, and D. Org. Lett. 2011, 13, 1118-1121.

17. Jaques, J.; Marquet, A. Selective $\alpha$-bromination of an aralkyl ketone with phenyltrimethylammonium tribromide: 2-bromoacetyl-6-methoxynaphthalene and 2,2-dibromoacetyl-6-methoxynaphthalene. Org. Synth. 1976, 53, 111.

18. Basheer, A.; Yamataka, H.; Ammal, S.C.; Rappoport, Z. Enols of substituted cyanomalonamides. J. Org. Chem. 2007, 72, 5297-5312.

19. Laliberté, R.; Médawar, G. $\beta$-Ketoalkylthioacrylic acid derivatives as precursors of thiophenes, thiazolines, and thienopyrimidines. Can. J. Chem. 1970, 48, 2709-2717.

20. Lyons, D.M.; Huttunen, K.M.; Browne, K.A.; Ciccione, A.; Trapani, J.A.; Denny, W.A.; Spicer, J.A. Inhibition of the cellular function of perforin by 1-amino-2,4-dicyanopyrido[1,2-a] benzimidazoles. Biorg. Med. Chem. 2011, 19, 4091-4110.

21. Magedov, I.V.; Luchetti, G.; Evdokimov, N.M.; Manpadi, M.; Steelant, W.F.A. Novel three-component synthesis and antiproliferative properties of diversely functionalized pyrrolines. Bioorg. Med. Chem. Lett. 2008, 18, 1392-1396.

22. Wang, S.L.; Yang, K.; Yao, C.S.; Wang, X.S. Green Synthesis of Quinazolinone Derivatives Catalyzed by Iodine in Ionic Liquid. Synth. Commun. 2012, 42, 341-349.

23. Kirincich, S.J.; Xiang, J.; Green, N.; Tam, S.; Yang, H.Y.; Shim, J.; Shen, M.W.H.; Clark, J.D.; McKew, J.C. Benzhydrylquinazolinediones: Novel cytosolic phospholipase A $2 \alpha$ inhibitors with improved physicochemical properties. Biorg. Med. Chem. 2009, 17, 4383-4405.

Samples Availability: Available from the authors.

(C) 2012 by the authors; licensee MDPI, Basel, Switzerland. This article is an open access article distributed under the terms and conditions of the Creative Commons Attribution license (http://creativecommons.org/licenses/by/3.0/). 